\title{
Factors associated with malnutrition among pregnant women and lactating mothers in Miesso Health Center, Ethiopia
}

\author{
Masresha Leta Serbesa ${ }^{1}$, Maleda Tefera Iffa $^{2}$, Mohammed Geleto ${ }^{3}$
}

\begin{abstract}
INTRODUCTION Malnutrition is one of the major problems in which the physical function of an individual is impaired to the point that it can no longer maintain adequate body processes such as growth, physical work, and resistance to or recovery from disease. Malnutrition is associated with a low economic situation, and poor personal and environmental hygiene. Recent studies found that the centre of the problem is the backward socioeconomic development of the country. The level of the healthcare services in Ethiopia is low, even when compared to sub-Sahara African countries. The objective of this study was to assess the magnitude of malnutrition and associated factors among pregnant women and lactating mothers in the Miesso Health Centre, Miesso Woreda, Oromia Region, Ethiopia.

METHODS A cross-sectional study was conducted from 1 February to 30 May 2017, among pregnant women and lactating mothers in Miesso Woreda. A sample of 304 women was selected using a systematic random sampling approach from the list of patients, with different sociodemographic status.

RESULTS Our results showed that among all pregnant women and lactating mothers, $12.6 \%$ were overweight and $30.3 \%$ were underweight. From multiple logistic regression analysis, family incomes ( $\mathrm{AOR}=2.056,95 \% \mathrm{Cl}$ : 1.051-4.023) and age of women (AOR=2.169, 95\% Cl: 1.015-4.634) were significantly associated with the nutritional status of the study participants.

CONCLUSIONS We recommend that authorities should: facilitate the rural-urban community's access to information on nutrition including eating-practices sanitation; initiate a health and development program during pregnancy and lactation; expand women's education on diet during pregnancy and lactation.
\end{abstract}

\section{AFFILIATION \\ 1 Department of Midwifery, Harar Health Science College, Harar, Ethiopia \\ 2 Department of Nursing, Haramaya \\ University, Harar, Ethiopia \\ 3 Miesso Health Center, Oromia Region, Ethiopia}

\section{CORRESPONDENCE TO}

Masresha Leta Serbesa. Department of Midwifery, Harar Health Science College, Harar, Ethiopia.

E-mail: masreshaleta3@gmail.com

\section{KEYWORDS}

magnitude, pregnancy, malnutrition

Received: 24 January 2019

Revised: 19 June 2019

Accepted: 19 June 2019

\section{INTRODUCTION}

The World Health Organization (WHO) defines malnutrition as 'the cellular imbalance between the supply of nutrients and energy and the body's demand for them to ensure growth, maintenance, and specific functions'. Contrary to the common use, the term malnutrition refers not only to deficiency states but also to excess and imbalance in the intake of calories, proteins and/or other nutrients ${ }^{1}$.

A balanced amount of nutrients is necessary for the proper functioning of the body system. Nutrition is a fundamental pillar of human life, health and development throughout the entire life span ${ }^{1}$. Proper food and good nutrition are essential for survival, physical growth, mental development, performance and productivity, health, and wellbeing. However, nutrition requirements vary with age, gender, and during physiological changes such as pregnancy. Pregnancy is such a critical phase in a woman's life when the expecting mother needs optimal nutrients of superior quality to support the developing fetus.

Malnutrition manifests itself as a function of many and complex factors that affect the national child status ${ }^{2}$. It is directly linked to inadequacy in diet and diseases under living conditions factors that include crisis in household food supply, inappropriate childcare and feeding practices, unhealthy place of residence and insufficient basic health services for those in poor socioeconomic situations, cultural beliefs, and lack of parents' education, especially that of mothers.

An adequate nutritional status of pregnant women is essential for their health and pregnancy outcomes. 
Due to increased nutritional requirements, pregnancy is a critical period for meeting the body's demand for macro/ micronutrients. Thus, anaemia and vitamin A deficiency (VAD) are common micronutrient deficiencies that affect 53.8 million pregnant women in the world ${ }^{3}$.

Poor nutrition in pregnancy, in combination with infections, is a common cause of maternal and infant mortality and morbidity, low birth weight and intrauterine growth retardation (IUGR). Malnutrition remains one of the world's highest priority health issues, not only because its effects are so widespread and long lasting but also because it can be eradicated best at the preventive stage ${ }^{4}$. Maternal malnutrition is influenced not only by lack of adequate nutrition but also influenced by social and psychological factors, nutritional knowledge of mothers, and biological changes that influence perceptions of eating patterns during pregnancies $^{5}$.

Many women in Africa suffer from chronic energy deficiency, inadequate weight gain during pregnancy, and poor micronutrient status. Insufficient food intake, high energy expenditure, micronutrient-deficient diets, infections, and the demands of pregnancy and lactation contribute to maternal malnutrition ${ }^{6}$.

Maternal mortality is unacceptably high. About 800 women die from pregnancy- or childbirth-related complications around the world every day ${ }^{7}$. In 2013, 289000 women died during and following pregnancy and childbirth. Almost all of these deaths occurred in low-resource settings, and almost all maternal deaths (99\%) occur in developing countries. More than half of these deaths occur in sub-Saharan Africa ${ }^{7}$.

Twenty per cent of maternal deaths in Africa have been attributed to anaemia ${ }^{8}$. In sub-Saharan Africa, iron and folate deficiencies are the most common causes of anaemia in pregnant women. Anaemia has a variety of converging contributing factors, but iron deficiency is the cause of $75 \%$ of anaemia cases. In Ethiopia, antenatal care (ANC) coverage by a skilled provider in 2011 was 34\%. Prevalence of anaemia among pregnant women was $22 \%$, but only $16.8 \%$ of pregnant mothers had taken iron tablets during pregnancy ${ }^{9}$.

Based on the above, the present study aims to assess the factors associated with malnutrition among pregnant women and lactating mothers attending antenatal care (ANC) clinics in Meisso Health Centre, Ethiopia.

\section{METHODS}

A cross-sectional study was conducted in Miesso Health Centre, Miesso Woreda, Oromia Region, Ethiopia, from 1 to 30 March 2017. The sample consisted of 304 randomly selected pregnant women and lactating mothers.

Sample size was determined by: using a single proportion sample size calculation formula with a source of population size greater than 10000; using a 41\% prevalence of malnutrition among pregnant women and lactating mothers, from previous studies done in Ethiopia; and setting the margin of error at $5 \%$ with $95 \%$ confidence interval, and a non-response rate of $10 \%$.
Western Hararghe is the fifth largest zone of the administrative zones of Oromia Regional State. It constitutes about $7 \%$ of the size of the region and covers $22623 \mathrm{~km}^{2}$. The population and housing census on 2008 indicate that the Zone was projected to have a population of 2739390 (Central Statistical Authority, CSA, 2008). Miesso Woreda has a population of 175313 and about 93604 are rural inhabitants (CSA, 2008). Health service coverage of the region is $85 \%$ with four public health centers and about 23 primary health posts, with 162 health care providers, in the Miesso Woreda, but no hospital.

A structured questionnaire, containing close-ended questions including information on malnutrition and related factors such as measurement of weight, height and calculation of BMI (body mass index, $\mathrm{kg} / \mathrm{m}^{2}$ ). The questionnaire was prepared in English and translated to Afan Oromo, a local language. Before data collection, the questionnaire was pre-tested on $5 \%$ of the patients, at a public health center in Oromia Region, who were not selected for the study but randomly selected from patients having a follow-up in the ANC clinic. In order to confirm the ethical and legal standards of the investigation, approval was obtained from the ethical review board of the Harar Health Science College. The survey was commenced after written consent was obtained from the Miesso Health Center. This helps to test the consistency and acceptability of the questionnaire. After finalizing the questionnaire by performing some necessary corrections, we trained the data collectors for 3 days. During data collection, the questionnaire was checked for completeness on a daily basis by the data collectors and the supervisors. The completed questionnaire was also rechecked by the principal investigators to maintain the quality of data.

After data collection, each questionnaire was checked for completeness, then coded and entered into Epi-info version 3.5.1 for cleaning, editing, and analysis. The results were presented in the form of tables, figures and text using frequencies and summary statistics such as mean, mode, standard deviation and percentage, to describe the study population in relation to relevant variables.

\section{RESULTS}

The sociodemographic profile of the sample is presented in Table 1. Pregnant women were more than lactating mothers (55\% vs $45 \%$ ). Most of the women were aged $20-30$ years, lived in rural areas, had primary school education or were illiterate, and Muslim. The majority worked as farmers with a monthly income of $>1000$ ETB (Ethiopian birr) (US\$1 is about 29 ETB). Additionally, more than half drank unprotected water and almost half of them had access to a toilet.

Table 2 shows the anthropometric measurements of pregnant women and lactating mothers in Miesso Health Center. According to the results, most of the women have a normal BMI while 30.3\% are underweight.

Table 3 presents the nutritional status of the pregnant women and lactating mothers that participated in the study, in Miesso Health Center. The majority (83.38\%) 
Table 1. Sociodemographic characteristics of pregnant women and lactating mothers in Miesso Health Center $(\mathrm{N}=304)$

\begin{tabular}{|c|c|c|}
\hline Respondents & Frequency & Percentage \% \\
\hline Pregnant women & 166 & 55 \\
\hline Lactating mothers & 138 & 45 \\
\hline Characteristics & Categories & Frequency \\
\hline \multirow[t]{2}{*}{ Residence } & Urban & 178 \\
\hline & Rural & 126 \\
\hline \multirow[t]{4}{*}{ Age (years) } & $\leq 20$ & 38 \\
\hline & $20-30$ & 113 \\
\hline & $31-40$ & 89 \\
\hline & $41-49$ & 64 \\
\hline \multirow[t]{3}{*}{ Educational status (grades) } & Primary (1-8) & 150 \\
\hline & Secondary (9-12) & 27 \\
\hline & Illiterate & 127 \\
\hline \multirow[t]{3}{*}{ Religion } & Orthodox & 65 \\
\hline & Muslim & 217 \\
\hline & Protestant & 22 \\
\hline \multirow[t]{4}{*}{ Occupation } & Farmer & 127 \\
\hline & Merchant & 82 \\
\hline & Civil servant & 59 \\
\hline & Other & 36 \\
\hline \multirow[t]{2}{*}{ Family members } & $<4$ & 216 \\
\hline & $\geq 4$ & 88 \\
\hline \multirow[t]{3}{*}{ Monthly income ETB } & $\leq 1000$ & 143 \\
\hline & 1000-2000 & 69 \\
\hline & $>2000$ & 92 \\
\hline \multirow[t]{2}{*}{ Latrine utilization } & Yes & 178 \\
\hline & No & 126 \\
\hline \multirow[t]{2}{*}{ Source of drinking water } & Pipe water & 178 \\
\hline & Unprotected water & 209 \\
\hline
\end{tabular}

a Exchange: US\$1 is about 29 ETB (Ethiopian Birr).

Table 2. Anthropometric measurements of pregnant women and lactating mothers in Miesso Health Center $(\mathrm{N}=304)$

\begin{tabular}{|lccc|}
\hline Measurements & Frequency & Median & Range \\
\hline Weight $(\mathrm{kg})$ & 124 & 40.8 & $51.5-60.0$ \\
& 180 & 59.2 & $60.0-77.5$ \\
\hline Height $(\mathrm{m})$ & 176 & 1.58 & $1.56-1.60$ \\
& 128 & 1.66 & $1.61-1.78$ \\
\hline $\mathrm{BMl}\left(\mathrm{kg} / \mathrm{m}^{2}\right)$ & Categories & Frequency & Percentage \\
& $\begin{array}{l}\text { Overweight } \\
\text { >25.0 }\end{array}$ & 38 & 12.5 \\
& $\begin{array}{l}\text { Underweight } \\
\text { <18.5 }\end{array}$ & 92 & 30.3 \\
& Normal & 174 & 57.2 \\
& & & \\
& & &
\end{tabular}

of the women have knowledge regarding their nutritional status while $67.1 \%$ are vegetarian and $22 \%$ eat meat and dairy products. Most of them eat 2-3 times within 24 hours as they follow no specific dietary regimen. Most of them $(77.3 \%)$ use iodize salt to cook, do not eat fruit and vegetables (85.2\% vs $68.8 \%$, respectively), do not use iron supplements during pregnancy or lactating period (75.0\%), and they do not consume more carbohydrates.

Table 4 presents the health practices of pregnant women and lactating mothers who participated in the study. As shown, most of them visit the health centre often (87.2\%), they have not utilized family planning (92.4\%) and they give birth within a year from the last delivery (71.1\%). The majority of the participants report that they receive good care (55.6\%), although $72.0 \%$ do not use additional food while pregnant/lactating.

After bivariate analysis, multivariate analysis of logistic regression was performed to filter the net effect of each independent variable associated in the bivariate model analysis with nutritional status of pregnant women and

Table 3. Nutritional status of the pregnant women and lactating mothers in Miesso Health Center $(\mathrm{N}=304)$

\begin{tabular}{|c|c|c|c|}
\hline & Categories & Frequency & Percentage \% \\
\hline \multirow{2}{*}{$\begin{array}{l}\text { Knowledge of } \\
\text { nutritional status }\end{array}$} & Yes & 51 & 16.62 \\
\hline & No & 253 & 83.38 \\
\hline \multirow[t]{3}{*}{ Dietary style } & Vegetarian & 204 & 67.1 \\
\hline & $\begin{array}{l}\text { Meat } \\
\text { and dairy } \\
\text { products }\end{array}$ & 67 & 22 \\
\hline & Both equally & 33 & 10.9 \\
\hline \multirow{3}{*}{$\begin{array}{l}\text { Meals within } 24 \\
\text { hours }\end{array}$} & $>3$ & 78 & 25.7 \\
\hline & 3 & 130 & 42.8 \\
\hline & 2 & 96 & 31.6 \\
\hline \multirow{2}{*}{$\begin{array}{l}\text { Following specific } \\
\text { dietary regimen }\end{array}$} & Yes & 56 & 18.42 \\
\hline & No & 248 & 81.58 \\
\hline \multirow{2}{*}{$\begin{array}{l}\text { Using iodized salt to } \\
\text { cook main meal }\end{array}$} & Yes & 235 & 77.3 \\
\hline & No & 69 & 22.7 \\
\hline \multirow{2}{*}{$\begin{array}{l}\text { Habit of consuming } \\
\text { fresh citrus fruits/ } \\
\text { juices }\end{array}$} & Yes & 45 & 14.8 \\
\hline & No & 259 & 85.2 \\
\hline \multirow{2}{*}{$\begin{array}{l}\text { Eating fruits and } \\
\text { vegetables }\end{array}$} & Yes & 95 & 31.3 \\
\hline & No & 209 & 68.8 \\
\hline \multirow[t]{2}{*}{ Iron supplements } & Yes & 76 & 25 \\
\hline & No & 228 & 75 \\
\hline \multirow{2}{*}{$\begin{array}{l}\text { Frequency of more } \\
\text { than usual meals } \\
\text { per day }\end{array}$} & Yes & 83 & 27.30 \\
\hline & No & 221 & 72.70 \\
\hline \multirow{2}{*}{$\begin{array}{l}\text { Habit of eating } \\
\text { more carbohydrates }\end{array}$} & Yes & 73 & 24 \\
\hline & No & 231 & 76 \\
\hline \multirow{2}{*}{$\begin{array}{l}\text { Eating protein, e.g. } \\
\text { meat, milk and milk } \\
\text { products daily }\end{array}$} & Yes & 129 & 42.4 \\
\hline & No & 175 & 57.6 \\
\hline
\end{tabular}




\section{Table 4. Healthcare practices of pregnant women and lactating mothers in Meisso Health Centre $(\mathrm{N}=304)$}

\begin{tabular}{lccc} 
Variables & Categories & Frequency & Percentage \% \\
\hline $\begin{array}{l}\text { Often visits the } \\
\text { health centre }\end{array}$ & Yes & 265 & 87.2 \\
Family planning & Yes & 39 & 12.8 \\
utilization & No & 281 & 7.6 \\
\hline $\begin{array}{l}\text { Methods of family } \\
\text { planning }\end{array}$ & Pills & 6 & 2.4 \\
\hline $\begin{array}{l}\text { Care of pregnant } \\
\text { women and }\end{array}$ & Good & 17 & 5.6 \\
lactating mothers & None & 169 & 55.6 \\
$\begin{array}{l}\text { Birth interval (years) } \\
\text { from last delivery }\end{array}$ & 1 & 216 & 44.4 \\
$\begin{array}{l}\text { Use of additional } \\
\text { food for pregnant }\end{array}$ & Yes & 88 & 71.1 \\
$\begin{array}{l}\text { women/lactating } \\
\text { mothers }\end{array}$ & No & 219 & 28.9 \\
\end{tabular}

Centre, and gives the association of sociodemographic characteristics and nutritional status of 304 participants. The study is a reasonable reflection of the nutritional status of the pregnant women and lactating mothers. A number of similar studies have been conducted in various parts of other countries.

Different studies show that education plays a prominent role on the nutritional status of pregnant women and lactating mothers. The majority of the respondents in our study were illiterate or had primary education, which may explain the diet they followed at the time of our study. Family education affects nutrition and is associated with a higher income and the participant's ability to make better decisions for herself and her child. The educated pregnant women and lactating mothers were more careful about what they ate than the uneducated ones. A study in the urban slums of Dibrugarah showed that the prevalence of malnutrition was much higher among low income and illiterate women. These findings agree with ours.

According to the findings of our study, families with many members is also an important factor related to the

Table 5. Multivariate logistic regression of nutritional status of pregnant women and lactating mothers $(\mathrm{N}=304)$

\begin{tabular}{|c|c|c|c|c|c|}
\hline \multirow[t]{2}{*}{ Variable } & \multirow[t]{2}{*}{ Categories } & \multicolumn{2}{|c|}{$B M I\left(k g / m^{2}\right)$} & \multirow[t]{2}{*}{$p$} & \multirow[t]{2}{*}{ AOR $(95 \% \mathrm{CI})$} \\
\hline & & $\begin{array}{c}\text { Underweight (<18.5) } \\
n(\%)\end{array}$ & $\begin{array}{c}\text { Normal }(\geq 18.5) \\
n(\%)\end{array}$ & & \\
\hline \multirow[t]{4}{*}{ Monthly income } & $\leq 1000$ & 73 (79.35) & $71(33.49)$ & 0.035 & 2.056 (1.051-4.023) \\
\hline & 1001-2000 & $17(18.47)$ & $51(24.05)$ & 0.001 & $5.632(2.694-11.777)$ \\
\hline & $>2000$ ETB $^{a}$ & $2(2.17)$ & $90(42.46)$ & & \\
\hline & Total & 92 & 212 & & \\
\hline \multirow[t]{5}{*}{ Age } & $\leq 20$ & $12(13)$ & $26(12.26)$ & & \\
\hline & $21-30$ & $19(20.7)$ & $94(44.34)$ & 0.108 & $2.172(0.843-5.598)$ \\
\hline & $31-40$ & $40(43.5)$ & $49(23.12)$ & 0.046 & 2.169 (1.015-4.634) \\
\hline & $41-49$ years & $21(22.8)$ & $43(20.28)$ & 0.638 & $1.474(0.665-3.267)$ \\
\hline & Total & 92 & 212 & & \\
\hline
\end{tabular}

a Exchange: US\$1 is about 29 ETB (Ethiopian Birr).

lactating mothers, by controlling for the other independent variables. In a multivariate logistic regression analysis (Table 5), family income and age were found to have significant association with nutritional status of pregnant women and lactating mothers. Concerning family income, the pregnant women and lactating mothers who had a monthly income greater than 2000 ETB were less likely to be underweight than those who earned less than 1000 ETB (AOR=2.056, 95\% Cl: 1.051-4.023). Those mothers aged $21-30$ years were less likely to be underweight than mothers older than 30 years $(\mathrm{AOR}=2.172,95 \% \mathrm{Cl}$ : $0.843-5.598)$

\section{DIscussion}

This study reports on the magnitude of malnutrition among pregnant women and lactating mothers, in Miesso Health nutritional status of pregnant women and lactating mothers. The reason is that there is probably not enough time for proper care and enough food for them, increasing the risk of malnutrition. The effect of large family size with overcrowding and inadequate spacing has been implicated as a risk factor for the prevalence of malnutrition.

The results of this study also show that pregnant women and lactating mothers with malnutrition live in a household with low monthly family income.

Monthly income and attitude during pregnancy were identified as important predictors of knowledge of women on nutrition during pregnancy and lactation among the study participants. A similar study conducted in Wollega showed that educational level and monthly income were significantly associated with maternal knowledge on nutrition ${ }^{4}$. 
According to the responses on dietary style, a few were drinking fresh citrus fruit juice, almost a quarter were taking protein daily, and many were using milk and milk products daily, while a quarter were eating fresh vegetables, daily.

The weight and height of the pregnant women and lactating mothers were also measured in the study and the BMI was calculated. In all, 22.5\% were overweight, 30.3\% were underweight, and $47.2 \%$ of the pregnant women and lactating mothers had a normal nutritional intake. A study conducted in the rural community of the Tigray region indicated that about $25.5 \%$ and $58.3 \%$ were stunted or thin, respectively. Similarly, a study in the Jimma Zone to identify socioeconomic factors associated with underweight and stunting among adolescents found that most of the underweight adolescents (53.20\%) were females. According to the 2011 Demographic and Health Survey of Ethiopia (EDHS, 2011), about 27\% of women aged 15-49 years are thin, $9 \%$ are moderately or severely thin, and only $6 \%$ are overweight or obese.

\section{CONGLUSIONS}

Education is one of the most important resources that enables the family to provide appropriate care for pregnant women and lactating mothers in terms of growth and development. The risks are increased when the monthly income is lower than 1000 ETB. According to our results, the large family size seen in the area was one of the factors affecting nutritional status. We found evidence that socioeconomic and demographic variables have a significant influence on the nutritional status of pregnant women and lactating mothers. Therefore, further actions are needed to address these problems and the implementation of effective strategies.

Based on the result of our study, we recommend that authorities should:

- Facilitate rural-urban community's access to information on nutrition such as eating-practices sanitation, health, and development programs.

- Make efforts to expand awareness of women's education on dietary issues during pregnancy and lactation.

- Develop educational programs about nutritional problem identification and solutions, especially on community education about specific nutritional needs of pregnant women and lactating mothers, and how to combat the main infectious diseases.

\section{REFERENGES}

1. World Bank. Repositioning nutrition as central to development: A strategy for large scale action. Washington, DC: World Bank; 2006. https:// openknowledge.worldbank.org/handle/10986/7409. Accessed January 24, 2019.

2. Ronsmans C, Graham WJ. Maternal mortality: who, when, where, and why. The Lancet. 2014;368(9542):11891200. doi:10.1016/s0140-6736(06)69380-x

3. Latifa MF, Manal HA, Nihal S. Shehab Nutritional Awareness of Women during Pregnancy. J Am Sci.
2012;8(7):494-502. doi:10.7537/marsjas080712.77

4. Daba G, Beyene F, Fekadu H, Garoma W. Assessment of Knowledge of Pregnant Mothers on Maternal Nutrition and Associated Factors in Guto Gida Woreda, East Wollega Zone, Ethiopia. J Nutr Food Sci. 2013;3(6):235. doi:10.4172/2155-9600.1000235

5. Temesgen DH, Dessalegn W, Habtamu FG, Dunkana NK. Nutritional Status and Associated Factors Among Lactating Mothers in Nekemte Referral Hospital and Health Centers, Ethiopia. International Journal of Nutrition and Food Sciences. 2015;4(2):216-222. doi:10.11648/j.ijnfs.20150402.23

6. Idowu OA, Mafiana CF, Dapo S. Anaemia in pregnancy: a survey of pregnant women in Abeokuta, Nigeria. Afr Health Sci. 2005;5(4):295-259. PMID: 16615838.

7. Yifru B, Asres B. Commentary: actions in the pipeline and the way forward to reduce maternal and perinatal mortality in Ethiopia. Ethiop J Health Sci. 2014;24(O Suppl):149-168. doi:10.4314/ejhs.v24i0.13s

8. Central Statistical Agency, ICF International. Ethiopia Demographic and Health Survey 2011. Addis Ababa, Ethiopia and Calverton, Maryland: Central Statistical Agency and ICF International; 2012. https:// dhsprogram.com/pubs/pdf/FR255/FR255.pdf. Accessed January 24, 2019.

9. Roba KT, O'Connor TP, Belachew T, O'Brien NM. Seasonal variation in nutritional status and anemia among lactating mothers in two agro-ecological zones of rural Ethiopia: A longitudinal study. Nutrition. 2015;31(10):1213-1238. doi:10.1016/j.nut.2015.03.007

\section{CONFLIGTS OF INTEREST}

The authors have completed and submitted the ICMJE Form for Disclosure of Potential Conflicts of Interest and none was reported.

\section{FUNDING}

There was no source of funding for this research.

\section{PROVENANGE AND PEER REVIEW}

Not commissioned; externally peer reviewed. 